\title{
Pursuing Over-Criminalization at the EXPENSE OF ISLAMIC LAW
}

\author{
Adnan A. Zulfiqar \\ Rutgers Law School
}

\begin{abstract}
In a short essay, Adnan A. Zulfiqar takes a more critical approach to aspects of Brunei's criminal laws that have garnered less attention but that he finds more troubling. The international community has, rightly in his view, protested against and condemned the law's potential violations of human rights norms against torture and individual freedom. Most condemnations have focused on provisions for capital punishment, whipping, and amputation for the new Code's crimes of liwāt (sodomy), zinā (unlawful sexual intercourse between heterosexuals), and theft. But little attention has been paid to the Code's departures from "classical Islamic law's substantive and procedural constraints" thus allowing legislators and prosecutors to "criminalize more conduct." For example, the Code permits punishment of offenders who lack legal capacity, requires four eyewitnesses to prove rape, and prosecutes beliefs through punishing attempted apostasy. For these reasons, despite the procedural protections and heightened standards of doubt jurisprudence to which Mohamed and Müller point, the new Code entails many other provisions that signal the need for greater caution and perhaps further modification. Zulfiqar argues that Brunei codified Islamic criminal law in a way that creates novel crimes and disregards defendant rights, thus diverging from norms of fairness and cultural accommodation present in the precedents and mores of the very Islamic system which it seeks to reinterpret for its society today.
\end{abstract}


Brunei's recent implementation of a new penal code (hereafter "the Code") has drawn condemnation from many quarters, including calls to boycott the Sultan of Brunei's overseas investments. ${ }^{1}$ The harshest criticism has been reserved for sections of the Code that conflict with human rights norms on torture and individual freedom, specifically the inclusion of severe punishments for liwāt (sodomy), zinā (unlawful sexual intercourse between heterosexuals), and theft. ${ }^{2}$ While these sections deserve attention, other less-noticed parts of the Code are potentially of greater concern. Broadly speaking, the Code's overall disposition frequently ignores classical Islamic law's substantive and procedural constraints in favor of criminalizing more conduct.

Hence, while Brunei's Code purports to align itself with Islamic law, there are several provisions that represent significant departures from classical Islamic law and its prescribed limitations. Perhaps the most glaring example is the Code's decision to punish "persons without legal capacity," described as "not mukallaf" in the Code. ${ }^{3}$ Historically, like most legal systems, Islamic

1 Lauren M. Holson \& Emily S. Rueb, Brunei Hotel Boycott Gathers Steam as Anti-Gay Law Goes into Effect, N.Y. Times (Apr. 3, 2019), https://www.nytimes. com/2019/04/03/world/asia/brunei-hotel-boycotts.html [https://perma.cc/G57VRP3Z]; L.A. Will Press Boycott of Beverly Hills Hotel Despite Brunei Death Penalty Reprieve, L.A. Times (May 8, 2019), https://www.latimes.com/local/lanow/la-mebeverly-hills-hotel-boycott-20190508-story.html [https://perma.cc/WH8X-NV7V]; Kate Rooney, Wall Street Banks Boycott Brunei-Owned Hotels After Kingdom Makes Homosexuality Punishable by Death, CNBC (Apr. 29, 2019), https://www.cnbc. com/2019/04/29/wall-street-boycotts-brunei-owned-hotels-after-gay-death-penaltylaw.html [https://perma.cc/NCT5-SMUU]; Jack Sidders \& Will Mathis, U.K. Property Brokers Shun Brunei Fund over Anti-Gay Laws, Bloomberg (May 2, 2019), https://www.bloomberg.com/news/articles/2019-05-02/u-k-property-brokers-saidto-shun-brunei-fund-for-anti-gay-laws [https://perma.cc/4U3T-ZMMA]; U.N. Joins Clooney in Decrying "Inhuman” Brunei Anti-Gay Law, Guardian (Apr. 1, 2019), https://www.theguardian.com/world/2019/apr/01/brunei-cruel-and-inhuman-law-onstoning-for-gay-sex-condemned-by-un [https://perma.cc/R4PV-T9VW].

2 Brunei's Pernicious New Penal Code, Human Rights Watch (May 22, 2019), https://www.hrw.org/news/2019/05/22/bruneis-pernicious-new-penal-code [https://perma.cc/Y6NH-QKRG]; Francesca Paris, Death by Stoning Among Punishments in New Brunei Anti-LGBT, Criminal Laws, NPR (Apr. 3, 2019), https://www. npr.org/2019/04/03/709359137/death-by-stoning-among-punishments-in-new-brunei-anti-lgbt-criminal-laws [https://perma.cc/3D5G-JZJD].

3 Syariah Penal Code Order (SPCO) 2013 (No. S 69) (Oct. 22, 2013) [hereinafter SPCO], http://www.agc.gov.bn/AGC\%20Images/LAWS/Gazette_PDF/2013/ EN/s069.pdf [https://perma.cc/VUL5-W8QM]. See, e.g., SPCO § 70 (2013) 1704-05. 
law assessed capacity prior to assigning legal responsibility or criminal liability. ${ }^{4}$ While Brunei's Code recognizes various excuse defenses for incapacity, at various points it also inexplicably punishes actors it does not deem legally responsible. ${ }^{5}$ For instance, SPCO $§ 70$ punishes zinā committed by persons without legal capacity, including pre-pubescent minors (non-bāligh). ${ }^{6}$ One might be tempted to think Brunei views zinā as a strict liability crime, however this is not the case; various other provisions in Part II of the Code account for mental state. ${ }^{7}$ Rather, the Code is simply expanding criminalization and allowing actors that technically lack legal capacity to somehow attain the required mental state for the prohibited conduct.

Furthermore, although the Code includes Islamic law's traditional evidentiary requirement of four eyewitnesses to establish liability for zina $\bar{a}$, the Code considers absence of this evidence as only a partial defense. ${ }^{8}$ Instead, the Code creates a second-tier zina $\bar{a}$ crime where the four eyewitnesses may not be present but "other" evidence exists. ${ }^{9}$ This structure departs from the norms of classical Islamic law, where failure to produce four witnesses in a case involving consensual, non-marital sexual intercourse constituted a complete defense. ${ }^{10}$ In fact, the absence of four credible

4 Mawil Izzi Dien, Islamic Law: From Historical Foundations to Contemporary Practice 102 (2004) ("[A]n individual who is unable to under the rules of the law is not viewed as a responsible subject of the law, mukallaf."); AHMAD Hasan, The Principles of Islamic Jurisprudence: The Command of the Shari aH AND JURIDICAL NORM 292-96 (1993).

5 SPCO $\S \S 12$ ("Act of child who is not mumaiyiz"), 13 ("Act of child who is mumaiyiz but not baligh"), and 14 ("Act of person of unsound mind") (2013), 1682.

6 SPCO $§ 70$ (2013), 1704-05.

7 See, e.g., SPCO $§ 6(2013)$ ("[N]othing is an offense which is done by a person who...in good faith believes himself to be bound by law to do it."); $\S 9$ (" $[\mathrm{N}]$ othing is an offense which is done...without any criminal intention or knowledge...."); $\S 17$ (" $[N]$ othing which is not intended to cause death, is an offence by reason of any harm....").

8 Rudolph Peters, Crime and Punishment in Islamic Law 60 (2005) ("[F]or proving this offence, very strict standards of evidence are applied: instead of the testimonies of two, those of four eyewitnesses are required....").

9 SPCO $\S 69(2), 1704$.

10 Hina Azam, Sexual Violation in Islamic Law: Substance, Evidence AND Procedure 220 (2015) (noting that the absence of four eyewitnesses who testify to the act or discrepancy in their testimonies lead to the case being "dropped"). 
eyewitnesses would trigger potential criminal penalty for false accusation, which suggests that prosecution of zinā crimes was not emphasized even if the underlying conduct was strongly discouraged. ${ }^{11}$ Against this classical framework, Brunei's Code protects "false accusations" as long as they are made in "good faith." ${ }^{2}$

Possibly the most disturbing departure from classical Islamic legal procedure in the Code is its requirement of four eyewitnesses in cases involving rape (zinā bi l-jabar). ${ }^{13}$ Conflating the evidentiary requirements for non-consensual as opposed to consensual circumstances not only lacks a basis in classical Islamic law, but has far-reaching consequences. This was demonstrated by the devastating effects of a similar evidentiary requirement for rape incorporated into Pakistan's 1979 Hudood Ordinance. ${ }^{14}$

The Code also contains other areas of expanded criminalization, such as ill-considered provisions regarding inchoate crimes, specifically attempts. For instance, the Code includes a provision that punishes attempted apostasy (irtidād). ${ }^{15}$ It notes that an attempt at apostasy will be punished the same as apostasy. As an example of what constitutes "attempted apostasy," the Code notes that simply being "determined to renounce" Islam is enough to trigger punishment for apostasy. By criminalizing "attempted apostasy" at a very early stage of preparation, the Code actually undermines classical Islamic legal doctrine on apostasy, which al-

11 PeTERs, supra note 8, at 63-64.

12 SPCO § 88 (2013), 1710-11.

13 SPCO § 76 (2013), 1707-08.

14 Under the 1979 Hudood Ordinance in Pakistan, a rape victim was required to produce four eyewitnesses to her rape. Failing to produce these four eyewitnesses would lead to the rape victim being arrested for falsely accusing someone of unlawful sexual intercourse. An estimated $80 \%$ of women in Pakistan's jails were charged for failing to produce evidence against their rapist or for confessing their own unlawful sexual intercourse by being pregnant with their rapist's child. See Dan McDougall, Fareeda's Fate: Rape, Prison and 25 Lashes, Guardian (Sept. 16, 2006), https://www.theguardian.com/world/2006/sep/17/pakistan.theobserver [https://perma.cc/5EZM-VA4E]. See generally Asifa Quraishi, Her Honor: An Islamic Critique of the Rape Laws of Pakistan from a Woman-Sensitive Perspective, $18 \mathrm{MicH}$. J. InT'L L. 287 (1997); Consensus on Amending Hudood Ordinance, News InT'L (Karachi) (June 12, 2006), http://www.thenews.com.pk/archive/print/643871-consensus-on-amending-hudood-ordinance [https://perma.cc/J78T-LFJ6].

15 SPCO $\S 71$ (2013), 1705. 
lowed numerous opportunities for retraction prior to accepting that someone was an apostate. In other words, classical Islamic law did not have a crime of attempted apostasy. ${ }^{16}$ Furthermore, in the pre-modern period, criminalizing apostasy was arguably justified due to its intimate connection to political treason; no such connection exists today. ${ }^{17}$ Similarly, in another instance, the Code punishes attempted zinā then provides an example of what would constitute an attempt: an unmarried couple lying down on the same bed. ${ }^{18}$ Again, the Code defines attempt at a very early stage, well before what would be considered "perpetration" of the crime. There is no indication that these two individuals are engaged in any intimacy, but their presence on the same bed is enough to trigger a penalty for attempted zinā.

In sum, Brunei's Code gives one pause from the standpoint of Islamic law and code drafting. In trying to achieve the comprehensiveness of modern criminal codes alongside misplaced notions of what Islamic criminal law should look like, Brunei ends up criminalizing far more conduct than classical Islamic law ever sought to sanction. Aside from the numerous issues outlined above, other serious problems exist, most notably the sparse mention of culpability requirements, ${ }^{19}$ poorly constructed accomplice liability, ${ }^{20}$ and a sharī $a$ catch-all provision ${ }^{21}$ that defeats the Code's fundamental purpose. These are alarming flaws for a Code that seeks to produce anything resembling a more just criminal law in Brunei, let alone one that can be considered faithful to classical Islamic law.

16 Peters, supra note 8, at 65.

17 Rudolph Peters \& Gert J.J. De Vries, Apostasy in Islam, 17 Die Welt DES ISLAMS 18 (1976).

18 SPCO § 88 (2013), 1710-11.

19 Part II of the SPCO (2013) discusses ideas like "knowledge," "intent," and even mistake, but it is not clear how other types of culpability, such as negligence, would be treated by the Code.

20 SPCO $\S \S 37-50$ (2013), 1690-1697.

21 SPCO $§ 253$ (2013), 1766 ("On any matter which is not expressly provided for in this Order, the Court shall follow Hukum Syara."). 